\title{
Nutritional evaluation of mature seeds of Enterolobium cyclocarpum (parota) from diverse ecological zones in western Mexico
}

\author{
Evaluación nutricional de semillas maduras de Enterolobium cyclocarpum (parota) \\ de diversas zonas ecológicas del oeste de México
}

\author{
Lucía Barrientos-Ramírez a*, J Jesús Vargas-Radillo a, Magdalena Segura-Nieto b, Ricardo Manríquez- \\ González $^{\text {a }}$ Fernando A López-Dellamary Toral ${ }^{a}$ \\ *Corresponding author: a Universidad de Guadalajara, Centro Universitario de Ciencias Exactas e Ingenierías, \\ Departamento de Madera, Celulosa y Papel, km 15,5 Carretera Guadalajara-Nogales, Las Agujas, Zapopan, Jalisco, \\ CP 45020, México, tel.: (33)-36820110 ext. 289, lbarrien@cucei.udg.mx \\ ${ }^{\text {b }}$ Centro de Investigación y de Estudios Avanzados del IPN, Departamento de Ingeniería Genética, \\ km 9,6 libramiento norte carretera Irapuato-León, Apdo. Postal 629, Irapuato, Gto. CP 36500, México.
}

\begin{abstract}
SUMMARY
There is little information on the agroecological characteristics and chemical composition of some wild forage species in Mexico, which can be proposed as alternatives for forage uses; therefore, the aim of this work was to assess the nutritional properties of Enterolobium cyclocarpum (common name: parota) mature seeds collected from several native habitat locations with distinct physiographic and ecological conditions in Jalisco in western Mexico. Physiographic data, coexisting vegetation, environmental conditions, soil type, mineral and organic content of soils from each site were determined. Seed nutritional values (amino acid profile, mineral content and in vivo protein degradability) were evaluated by proximate composition. Seed samples from Autlán exhibited the highest crude protein values, ethyl ether extract, histidine, phosphorus, dry matter digestibility and protein efficiency ratio. This site coincides with the highest contents in soil organic carbon, soil organic matter and phosphorus, and appropriate climatic conditions; while seeds with the lowest value of crude protein, dry matter digestibility, and protein efficiency ratio were collected from Puerto Vallarta, La Huerta and Amatitán, which are the locations with inferior soil fertility characteristics.
\end{abstract}

Key words: ecosystems, mineral content, proximate chemical analyses, digestibility, amino acids.

\section{RESUMEN}

Existe poca información relacionada con las características agroecológicas y de composición química de algunas especies forestales silvestres en México con potencial forrajero, que pueden ser alternativas para alimento animal; por ello, el objetivo de este trabajo fue evaluar las propiedades nutricionales de semillas maduras de Enterolobium cyclocarpum (parota) colectadas en diversos habitats nativos bajo diferentes condiciones fisiográficas y ecológicas de Jalisco en el occidente de México. En cada sitio se determinó datos fisiográficos, vegetación asociada, condiciones ambientales, tipo de suelo, así como su contenido mineral y orgánico. Se evaluó el contenido nutricional de las semillas mediante el método de composición proximal, perfil de aminoácidos, minerales y degradabilidad de la proteína in vivo. Las semillas de Autlán mostraron el mayor valor de proteína cruda, extractos en etil éter, histidina, fósforo, digestibilidad de la materia seca, y relación de eficiencia proteica. Este sitio de muestreo presentó el suelo con mayor contenido de carbono orgánico, materia orgánica y fósforo, así como aceptables condiciones climáticas Las semillas con el menor valor de proteína cruda, digestibilidad de la materia seca y relación de eficiencia proteica fueron colectadas en los sitios de Puerto Vallarta, La Huerta y Amatitán, los cuales presentaron suelos menos fértiles.

Palabras clave: ecosistemas, contenido mineral, análisis químico proximal, digestibilidad, aminoácidos.

\section{INTRODUCTION}

Mexico ranks fourth worldwide in biodiversity and endemism, having thirteen major vegetation types, with a total estimated forest cover of about 144,500,000 hectares (FAO 2010). Mexico has approximately 2,000 of the more than 20,000 leguminous species of the world (Sotelo 1981, Souza and Delgado 1993). Leguminous seeds are impor- tant protein sources, some essential amino acids, minerals, vitamins, essential fatty acids and fiber (Liu 1997, Sabuola et al. 2012). Many legumes have protein content between $20-40 \%$, or up to $60 \%$ (Lawal and Adebowale 2006). The amino acid profile in legume seeds is normally high in lysine and low in tryptophan and sulfur amino acids. Hence, they need to be used in combination with cereals, or supplemented with free methionine, to prevent developing 
sulfur-containing amino acid deficiencies (Yi et al. 2010).

Enterolobium cyclocarpum (Jacq.) Griseb. (Leguminosae), known in western Mexico as parota, has been deemed one of the most important legume species in tropical America, as a reserve and potential source of proteins. Leaves and pods have been reported to provide good forage for cattle while pods and seeds are known to be used locally for human consumption (Sotelo 1981, Castro et al. 2006). In some rural areas in Mexico where parota trees grow, people sometimes eat roasted seeds and mixed in soups when still green (Bressani and Elias1980).

It is a long-lived tree, 20 to $30 \mathrm{~m}$ tall, with trunks up to $3 \mathrm{~m}$ in diameter and foliage kept most of the year. Darkbright ovoid seeds (10 to 15) are contained in ear-shaped pods (Pennington and Sarukhan 1968), with yield of about $86 \mathrm{~kg}$ of pods per tree, containing $15.6 \%$ crude protein (Andrade et al. 2008). In a previous publication (Serratos et al. 2008) claim that E. cyclocarpum seeds had $26.3 \%$ of crude protein (CP), $2.8 \%$ of ether extracts (EE), and $63.1 \%$ of nitrogen free extractives (NFE).

This plant is now present in some other tropical regions in the world and has been the subject of many studies. The wood is employed in housing, furniture, cabinet making and other carpentry applications (Rocha and Lobo 1996).

Enterolobium cyclocarpum, although originally from the Americas, is currently distributed throughout the tropics (deciduous, subdeciduous, evergreen and subevergreen flora) and grows in an approximate area of 29 million hectares worldwide (FAO 2010). In Mexico E. cyclocarpum trees are part of the native flora and are distributed along the Gulf of Mexico coastal area and in the Pacific Coast along streams and rivers (Vázquez-Yanes et al. 1999, Pennington and Sarukhan 2005), preferably at altitudes of 0-800 meters above sea level (m a.s.l.). It grows best in sandy, sandy-clay and black soils (VázquezYanes et al. 1999). In the State of Jalisco, located in central-western Mexico, chosen in this study as the collection area, this species is mainly located in lowland tropical areas, with well differentiated dry and rainy seasons (Aw climate), mostly within the Pacific Ocean watershed (Rzedowski 1991, INE 1994). Enterolobium cyclocarpum is also located at higher altitudes, in the center of Jalisco, in fragmented relicts along the foothills of the Sierra Madre Occidental and the Trans-Mexican Volcanic Belt, under more temperate climatic conditions (Sedeur 2010). There is little information on the agronomical characteristics, chemical composition and toxicity of some wild species in Mexico, such as E. cyclocarpum, which could be an alternative for substituting import conventional forage. Also, the environment (altitude, temperature, relative humidity, etc.) of different locations plays an important role in determining the quality and quantity of proteins in seeds, it may be relatively more important than how plants are agriculturally grown (Dodd and Pushpamma 1980). The nutritional properties of seeds of this species under study would be different under diverse ecosystems in western Mexico. The information obtained from this study is expected to improve knowledge on the variability in the chemical composition as well as nutritional and digestibility properties of seeds of this species, in relation to its habitat. This also could be used to increase the information on this legume as an alternative source for the enrichment of foodstuffs with proteins and/or amino acids. Although in this work E. cyclocarpum is considered as an alternative for forage, it is important to consider that both pods and seeds have been used for human consumption in certain areas of Mexico since antiquity. Thus, the aim of this study was to assess the nutritional properties of E. cyclocarpum mature seeds, originated from native habitat sites with different climatic and soil conditions in the State of Jalisco.

\section{METHODS}

Collection sites. Mature seeds of E. cyclocarpum were collected, all within the State of Jalisco, in A) four tropical zones: (1) Puerto Vallarta (in the site known as Valle de Banderas), (2) Tomatlán (in the site known as Llano Grande-los Lindos), (3) La Huerta and (4) Autlán; B) one temperate central location: Amatitán (Achío Canyon) (figure 1). The type of vegetation, physiographic and ecological data were duly recorded.

Ecological characteristics of collecting sites. The most common ecosystem (table 1) was semi-deciduous tropical forest (STF), and subperenifolia (semi-evergreen tropical forest) distributed in thickets.

The climate of this area was Aw, tropical with marked wet and dry seasons. Soils were in general sandy-loam and clay loam (table 2). Physiography and ecological conditions of each collection site is described below.

- Puerto Vallarta. Specimens grew preferably on ground level where sandy-loam soils were deep as in Valle de Banderas (140 m a.s.l.). In this place, parota was abundant and coexisted with other species such as Brosimum alicastrum Sw, Ficus sp., Orbignya cohune (Mart.), Bursera simaruba (L.) Sarg. and Acacia sp.

- La Huerta. The collection site is in the valley La Huerta-Purificación on nonagricultural areas, E. cyclocarpum occupied protected sites along seasonal streams, on sandy loam soils. It grew frequently in conjunction to Hymenaea courbaril Linneaus and Pithecellobium dulce (Roxb.) Benth., Ficus sp. and Cordia elaeagnoides A. DC. This site was higher in altitude (300 m a.s.l.) than Valle de Banderas in Puerto Vallarta.

- Tomatlán. A collection of samples was done in the location known as Llano Grande-los Lindos with a hilly physiography, sandy loam soils. Enterolobium cyclocarpum was abundant, with trunk diameters between 30 and $40 \mathrm{~cm}$ and coexisted with Sabal pumos (Kunth) Burret, Ficus sp., Castilla elastica sp., Pseudobombax ellipticum (Kunth) Dugand, Hura polyandra Baill., Spondias mombin L., Bursera sp. and Acacia sp.

- Autlán. This was the highest collection site of the tro- 


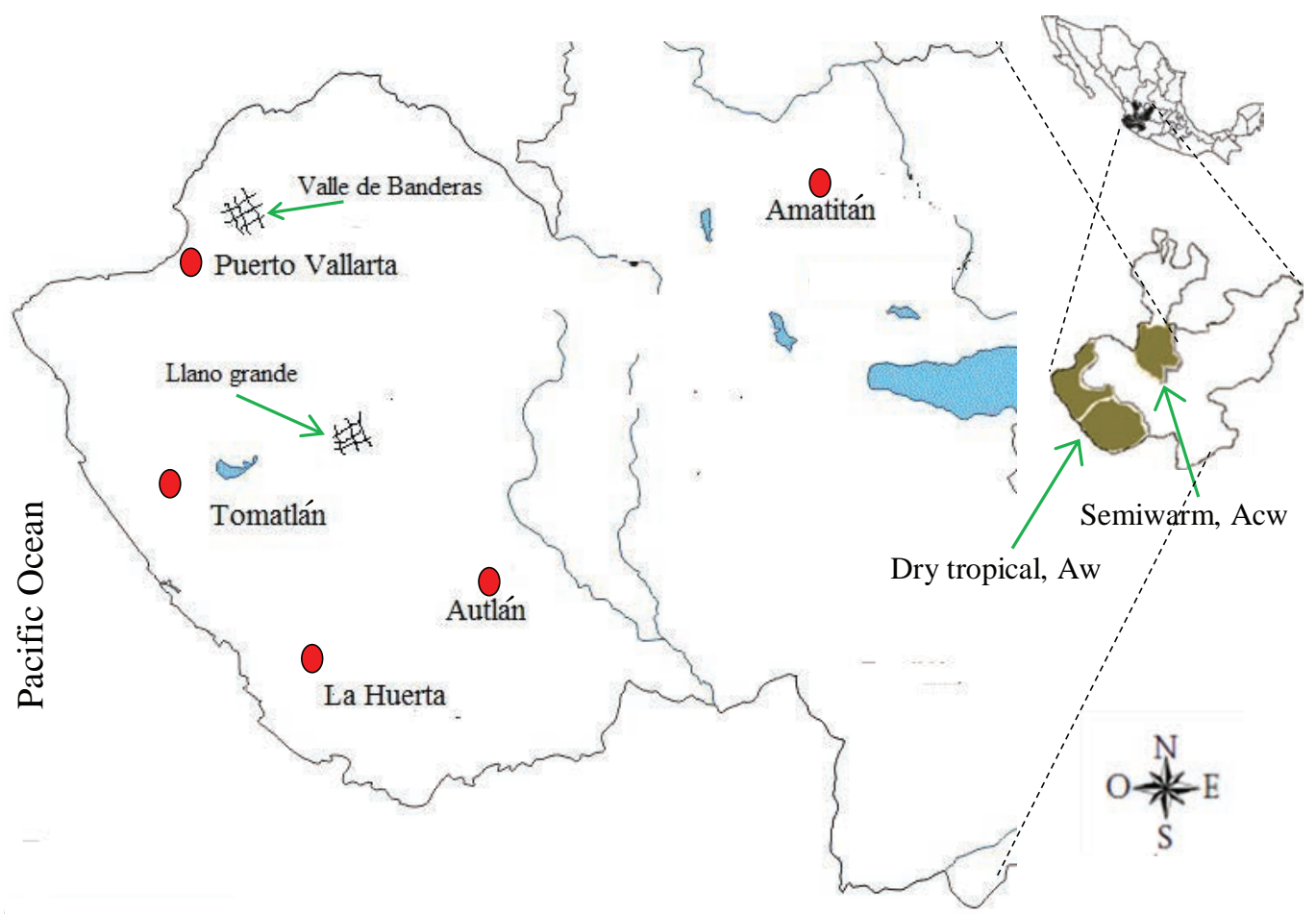

Figure 1. Collection sites. The map shows the geographical region in which the seeds of E. cyclocarpum were collected. Red dots show the capital cities of different regions, near collection sites.

Sitios de colecta. En el mapa se muestra la región geográfica en la que fueron colectadas las semillas de E. cyclocarpum. Los puntos rojos indican las capitales políticas de las diferentes regiones, cercanas a los sitos de recolección.

Table 1. Environmental and geographical characteristics of the collection sites.

Características ambientales y geográficas de los sitios de colecta.

\begin{tabular}{|c|c|c|c|c|c|c|c|}
\hline Site & $\begin{array}{c}\text { Elevation } \\
\text { (m a.s.l.) }\end{array}$ & $\begin{array}{c}\text { North } \\
\text { latitude }\end{array}$ & $\begin{array}{l}\text { Length } \\
\text { West }\end{array}$ & $\begin{array}{c}\text { Pluviometry }{ }^{1} \\
\left(\mathrm{~mm}_{\text {year-1) }} \text { ) }\right.\end{array}$ & $\begin{array}{c}\text { Temperature }^{1} \\
\left({ }^{\circ} \mathrm{C}\right)\end{array}$ & Weather & $\begin{array}{l}\text { Vegetation } \\
\text { type }\end{array}$ \\
\hline Puerto Vallarta $†$ & 140 & $20^{\circ} 27^{\prime}$ & $104^{\circ} 55^{\prime}$ & 892.2 & 26.9 & Aw & SELF \\
\hline Tomatlán† & 450 & $19^{\circ} 56^{\prime}$ & $105^{\circ} 14^{\prime}$ & 803.5 & 26.3 & Aw & STF \\
\hline Autlán† & 900 & $19^{\circ} 34^{\prime}$ & $104^{\circ} 07^{\prime}$ & 689.3 & 22.9 & $\mathrm{ACw}$ & STF \\
\hline La Huerta† & 300 & $19^{\circ} 20^{\prime}$ & $104^{\circ} 31^{\prime}$ & 908.4 & 27.0 & Aw & STF \\
\hline Amatitán * & 1,200 & $20^{\circ} 42^{\prime}$ & $103^{\circ} 37^{\prime}$ & 853.6 & 22.2 & $\mathrm{ACw}$ & STF (relict) \\
\hline
\end{tabular}

$\dagger$ Dry tropical region. *Semiwarm central zone. m a.s.1., meters above sea level. ${ }^{1}$ Average 1985-2010 (Ruiz et al. 2012 ).

Aw; tropical wet and dry; ACw; semi-warm (García 1973). STF; semi-deciduous tropical forest; SELF; Semi-evergreen lowland forest.

pical zone at $900 \mathrm{~m}$ a.s.l. Its physiography was relatively constant, with flatland surrounded by mountains of considerable altitude. Autlán had a deep loam soil, good for agriculture, only few areas remain with the original flora. E. cyclocarpum grew on the alluvial plains and along seasonal streams as well as some agricultural lands. Parota cohabited with Ipomoea intrapilosa Rose, Eucalyptus camandulensis Dehnh, Bursera sp., Lysiloma acapulcensis (Kunth) Benth., Prosopis lea- vigata (Humb. et Bonpl. ex Willd) and Pithecellobium $\mathrm{sp}$. as the most salient specimens of the local flora.

- Amatitán. Situated at 1,200 m a.s.l., was the only collection zone outside the tropics; it is located in central Jalisco. This site presents relics of an old tropical forest, now modified by agricultural activities. In the Achío Canyon microclimate, E. cyclocarpum grew coexisting with Ficus cotinifolia Kunth, Annona sp., Pithecellobium sp. and Bursera sp. 
Sampling. The area for sampling was one hectare for each study site. The taxonomic identification was carried out by analyzing the anatomy of seeds, branches and foliage collected from five randomly determined trees, which were compared with already existent specimens at the Department of Botany Herbarium, University of Guadalajara (IBUG), Mexico. Soils were sampled by taking portions of around $20 \mathrm{~g}$ at a depth of $15 \mathrm{~cm}$, in three different zones in the site; subsequently, they were mixed to produce a composite sample, which was afterwards stored in jars. Soil texture was evaluated by the hand texture method (USDA 1999).

Sample preparation. The seeds were manually extracted from the pods, washed in distilled water and dried at $55-60^{\circ} \mathrm{C}$ for $48 \mathrm{~h}$. One $\mathrm{kg}$ of dried seeds for each site was ground using a mill (Wiley, 60-mesh screen) to flour consistency. Moisture was determined for dry matter estimation. Flour samples were stored in sealed plastic bags, at $5{ }^{\circ} \mathrm{C}$ to prevent fungal and microbial contamination, for subsequent analyses. Chemical analyses of the samples were carried out in triplicate $(\mathrm{n}=3)$ and the arithmetic means were expressed on a dry weight basis.

Analytical methods. Proximate composition was determined following the methods of the Association of Official Analytical Chemists (AOAC 1990): moisture, ash, nitrogen, ether extract (EE or fatty compounds), crude fiber (CF) and crude protein (CP) (\% N x 6.25). Nitrogen free extract (NFE or total digestible carbohydrates) was calculated by difference:

$$
\text { NFE \% (Dry basis })=100-(C P \%+C F \%+A s h)[1]
$$

Using these results, other nutritional qualities were calculated as follows: Total digestible nutrients yield (TDN) for a legume was assessed using the formula:

$$
\text { TDN } \%=74.43+0.43 \mathrm{CP} \%-0.73 \mathrm{CF} \%
$$

(Adams et al. 1964)

In addition, energy content, by using the formula:

$$
\frac{\mathrm{kJME}}{100 \mathrm{~g}}=18 \mathrm{CP}+39 \mathrm{EE}+17 \mathrm{NFE}
$$

Where,

$\mathrm{ME}=$ metabolisable energy (Schoenmaker and Beynen 2001).

Moreover, in order to perform amino acid analyses, samples were hydrolyzed with $6 \mathrm{~N} \mathrm{HCl}$ at $105^{\circ} \mathrm{C}$ for $24 \mathrm{~h}$ under inert atmosphere; afterwards, the samples were neutralized with $6 \mathrm{~N} \mathrm{NaOH}$ and the solids were separated by filtration (Urribarrí et al. 2004). Using precolumn derivatization with O-phthalaldehyde (OPA), the amino acid profile analysis was performed by reversed phase (C18 column)
HPLC (Varian) with fluorescence detection. Limiting essential amino acids were determined using as reference the standards established by the World Health Organization/ Food and Agriculture Organization of the United Nations/ United Nations University (WHO 2007). Chemical score measures the ratio among amino acids and the pattern of reference through the following equation:

$$
\begin{gathered}
\text { Essential amino acids chemical score } \\
=\frac{\mathrm{g} \text { of amino acids in sample }}{\mathrm{g} \text { of amino acids in pattern (WHO) }} \times 100
\end{gathered}
$$

Protein efficiency ratio (PER) and dry matter digestibility in vivo (DMD) were assayed according to AOAC (1990) methodology. Twenty male Wistar rats (28 days old) were used, placed individually in separate cages. Five lots, of four animals each, were fed during four weeks with a balanced diet that included the flour of E. cyclocarpum seeds from each collection site, to achieve a level of $10 \%$ of protein content in the feed preparation; casein was used as the protein source for the control (Ruiz and Sotelo 2001). The diets were regulated to have the same protein content. Food and water were offered ad libitum. Intake degree and body weight were recorded every two days, during 28 days.

Mineral composition analyses in soils and seeds were carried out by atomic absorption spectrophotometry (AAS) using a Perkin-Elmer spectrophotometer, model 2280. The content of macrominerals (calcium, magnesium, nitrogen (Kjeldahl method), phosphorus, potassium and sodium) and microminerals (copper, zinc) (Perkin Elmer 1996) was determined.

Statistics. The statistical design used for the chemical composition analyses was completely randomized, with the nutrimental parameters of seeds of each site as response variables. Data were analyzed using common descriptive statistics determining the mean and the standard deviation.

\section{RESULTS}

Minerals and characteristics of soils. All sites (table 2) exhibited sandy and clay loam soils with a pH slightly acidic or neutral.

Autlán soil presented the highest content in soil organic carbon (SOC) with $5.09 \%$; soil organic matter, $2.95 \%$; and phosphorus $0.09 \%$. Tomatlán soil composition showed the second highest content of soil organic carbon (4.96 \%) and the highest content of nitrogen (0.34 \%), as well as a high content of soil organic matter (2.84 \%). In contrast, Puerto Vallarta possessed the lowest content of soil organic carbon (1.11\%), soil organic matter (0.64 \%), nitrogen $(0.04 \%)$, potassium $(0.07 \%)$ and phosphorus $(0.01 \%)$. This zone showed the highest content of magnesium $(0.47 \%)$. 
Minerals in seeds. Regarding nutrient and mineral content in seeds (table 3), samples from the Autlán site presented the highest mineral content (minerals mean $=0.89 \%$ ); minerals such as nitrogen (2.91 \%), magnesium (0.32 \%) and phosphorus $(0.37 \%)$. These relatively high nitrogen and mineral contents in seeds could be attributed to some factors such as soil quality (morphology, chemistry, acidity) and the moderate climatic conditions of the transition forests of this region. In contrast, Puerto Vallarta seeds showed the lowest value of nitrogen $(2.07 \%)$ and phosphorus $(0.25 \%)$, although they presented the highest content of calcium (1.71\%).

Table 2. Minerals in soil and soil texture of collection sites of Enterolobium cyclocarpum.

Minerales en suelo y textura de suelo de los sitios de colecta de E. cyclocarpum.

\begin{tabular}{lccccccccc}
\hline \multirow{2}{*}{ Site } & \multicolumn{8}{c}{ Texture and minerals $\left(\mathrm{mg} 100^{-1} \mathrm{~g}^{-1}\right)$} \\
\cline { 2 - 10 } & Soil & $\mathrm{pH}$ & SOC & SOM & Ca & Mg & $\mathrm{K}$ & $\mathrm{N}$ & $\mathrm{P}$ \\
\hline Tomatlán & SL & 6.3 & $4.96 \pm 0.74$ & $2.84 \pm 0.62$ & $0.30 \pm 0.12$ & $0.33 \pm 0.12$ & $0.15 \pm 0.06$ & $0.34 \pm 0.17$ & $0.03 \pm 0.02$ \\
P Vallarta & SL & 7.9 & $1.11 \pm 0.16$ & $0.64 \pm 0.31$ & $0.39 \pm 0.21$ & $0.47 \pm 0.08$ & $0.07 \pm 0.05$ & $0.04 \pm 0.04$ & $0.01 \pm 0.01$ \\
Autlán & CL & 6.2 & $5.09 \pm 0.11$ & $2.95 \pm 0.70$ & $0.57 \pm 0.31$ & $0.27 \pm 0.15$ & $0.38 \pm 0.20$ & $0.24 \pm 0.13$ & $0.09 \pm 0.08$ \\
La Huerta & SL & 6.7 & $2.73 \pm 0.68$ & $1.58 \pm 0.62$ & $0.67 \pm 0.33$ & $0.20 \pm 0.16$ & $0.25 \pm 0.11$ & $0.18 \pm 0.15$ & $0.01 \pm 0.01$ \\
Amatitán & L & 6.7 & $4.35 \pm 0.46$ & $2.50 \pm 0.44$ & $0.47 \pm 0.30$ & $0.27 \pm 0.14$ & $0.73 \pm 0.28$ & $0.22 \pm 0.13$ & $0.01 \pm 0.01$ \\
\hline
\end{tabular}

SOC, soil organic carbon; SOM, soil organic material; N, nitrogen; Ca, calcium; K, potassium; P, phosphorus. SL, Sandy-Loam.

CL, Clay-Loam. L, Loam.

Table 3. Chemical composition (dry matter basis), energy and mineral content of Enterolobium cyclocarpum mature seeds from collection sites.

Composición bromatológica (base seca), energía y contenido de minerales de semillas maduras de E. cyclocarpum de los diferentes sitios de colecta.

\begin{tabular}{|c|c|c|c|c|c|}
\hline \multicolumn{6}{|c|}{ Collection site $(\bar{x} \pm s d)$} \\
\hline Nutrient (\%) & Tomatlán & Puerto Vallarta & Autlán & La Huerta & Amatitán \\
\hline Moisture & $9.05 \pm 0.59$ & $13.16 \pm 0.29$ & $10.0 \pm 0.62$ & $9.82 \pm 0.65$ & $11.35 \pm 0.05$ \\
\hline Dry matter & 90.95 & 86.84 & 90.0 & 90.18 & 88.65 \\
\hline Crude protein (Nx6.25) & $23.46 \pm 0.52$ & $20.93 \pm 0.89$ & $30.34 \pm 0.75$ & $22.11 \pm 0.7$ & $19.56 \pm 0.58$ \\
\hline Ether extract & $1.42 \pm 0.51$ & $1.93 \pm 0.11$ & $3.22 \pm 0.30$ & $1.66 \pm 0.55$ & $1.98 \pm 0.47$ \\
\hline Crude fiber & $14.19 \pm 0.61$ & $14.55 \pm 0.59$ & $13.50 \pm 0.60$ & $8.52 \pm 0.45$ & $8.14 \pm 0.67$ \\
\hline Ash & $4.0 \pm 0.53$ & $3.5 \pm 0.43$ & $4.0 \pm 0.65$ & $3.8 \pm 0.70$ & $4.6 \pm 0.61$ \\
\hline NFE & $56.93 \pm 0.92$ & $59.09 \pm 2.00$ & $48.94 \pm 1.68$ & $63.91 \pm 2.09$ & $65.72 \pm 1.89$ \\
\hline $\mathrm{ME}$ & $1445.47 \pm 10.8$ & $1456.5 \pm 13.7$ & $1503.68 \pm 24.1$ & $1549.2 \pm 6.62$ & $1546.5 \pm 16.9$ \\
\hline TDN & $72.28 \pm 0.98$ & $71.17 \pm 0.17$ & $75.20 \pm 0.22$ & $75.95 \pm 0.15$ & $75.34 \pm 0.43$ \\
\hline DMD & $62.1 \pm 2.31$ & $54.3 \pm 0.53$ & $62.1 \pm 0.78$ & $61.1 \pm 0.82$ & $58.2 \pm 0.69$ \\
\hline PER & $1.5 \pm 0.48$ & $1.2 \pm 0.52$ & $1.5 \pm 0.46$ & $1.0 \pm 0.28$ & $1.1 \pm 0.72$ \\
\hline \multicolumn{6}{|l|}{ Minerals: } \\
\hline Nitrogen & $2.21 \pm 0.71$ & $2.07 \pm 0.56$ & $2.91 \pm 0.80$ & $2.53 \pm 0.40$ & $2.49 \pm 0.49$ \\
\hline Calcium & $1.59 \pm 0.36$ & $1.71 \pm 0.55$ & $1.58 \pm 0.52$ & $1.62 \pm 0.54$ & $1.12 \pm 0.17$ \\
\hline Potassium & $0.82 \pm 0.07$ & $0.79 \pm 0.44$ & $0.77 \pm 0.70$ & $0.79 \pm 0.39$ & $0.81 \pm 0.10$ \\
\hline Magnesium & $0.32 \pm 0.03$ & $0.32 \pm 0.06$ & $0.32 \pm 0.06$ & $0.32 \pm 0.09$ & $0.28 \pm 0.10$ \\
\hline Sodium & $0.19 \pm 0.02$ & $0.19 \pm 0.11$ & $0.12 \pm 0.07$ & $0.09 \pm 0.07$ & $0.12 \pm 0.07$ \\
\hline Phosphorus & $0.28 \pm 0.02$ & $0.25 \pm 0.05$ & $0.37 \pm 0.07$ & $0.35 \pm 0.05$ & $0.32 \pm 0.06$ \\
\hline Copper & $0.05 \pm 0.02$ & $0.17 \pm 0.13$ & $0.16 \pm 0.07$ & $0.02 \pm 0.01$ & $0.26 \pm 0.06$ \\
\hline (minerals mean) & 0.78 & 0.78 & 0.89 & 0.82 & 0.77 \\
\hline
\end{tabular}

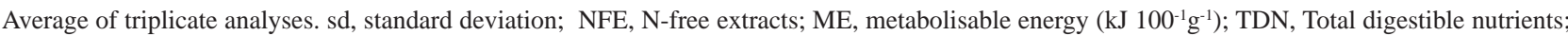
DMD, dry matter digestibility in vivo (degradability of dry matter); PER, protein efficiency ratio (casein control value, 2.4). 
Seed proximate composition and digestibility. Results obtained in the proximate chemical composition (table 3) showed that, in the case of crude protein (CP), the extreme values observed are between $19.56 \%$ and $30.34 \%$ from Amatitán and Autlán sites, respectively. The highest content of crude fiber (CF) $(14.55 \%)$ belonged to seeds from Puerto Vallarta, whereas the lowest contents were from Amatitán (8.14\%) and La Huerta (8.52 \%). The highest nitrogen free extract (carbohydrates) contents were found in samples from Amatitán (65.72 \%) and La Huerta (63.91 \%). In contrast, samples of Autlán showed the lowest value of this parameter with $48.94 \%$. Ether extract (EE) content (3.22 \%) of seeds from Autlán was the highest of all collection locations, while seeds from Tomatlán showed the lowest content (1.42\%). Total digestible nutrients (TDN), equation [2], and metabolisable energy (ME), equation [3], values involve the content of crude protein, ether extract and nitrogen free extract. The highest values of total digestible nutrients (75.95 \% and $75.34 \%$ ) and metabolisable

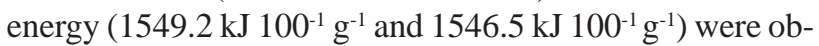
served in seeds from la Huerta and Amatitán, respectively. These high relative metabolisable energy values in samples of La Huerta and Amatitán were due to the high content of nitrogen free extract (63.91 \% and $65.72 \%$ ), notwithstanding these samples did not show the best values in crude protein and ether extract. Seeds from Autlán and Tomatlán showed the best digestibility properties, i.e. protein efficiency ratio $1.5 \%$ and dry matter digestibility $62.1 \%$.

Amino acids found in E. cyclocarpum seeds (table 4), are expressed in grams of amino acid per 100 grams of protein.

The amino acids (mean) of the collection sites were close or above the values established by the Food and Agricultura Organization (WHO 2007). Aspartic acid had the hig-

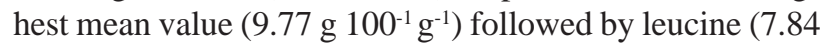
g $100^{-1} \mathrm{~g}^{-1}$, chemical score of $124.4 \%$ ) and arginine (7.38 g $\left.100^{-1} \mathrm{~g}^{-1}\right)$. Likewise, the lowest mean values corresponded to the aromatic amino acid phenylalanine with $4.08 \mathrm{~g} 100^{-}$ ${ }^{1} \mathrm{~g}^{-1}$ and chemical score of 88.7 (4.6\% pattern, WHO 2007)

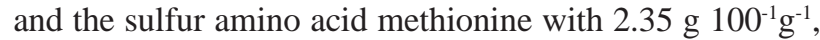
90.7 chemical score (2.6 \% pattern, WHO 2007), therefore these amino acids constituted the limiting in seeds from almost all locations. This is to be expected for a legume. Another important result was the mean by collection sites. Samples from La Huerta showed the highest average with

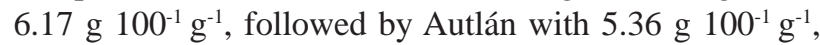

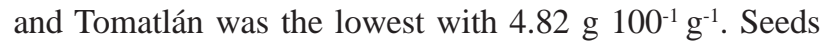
from La Huerta showed the highest content of any amino acid, aspartic acid (11.77 g 100 $\left.\mathrm{g}^{-1} \mathrm{~g}^{-1}\right)$, and methionine from

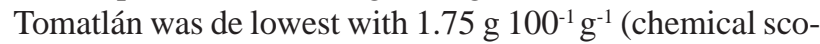
re $67.3 \%$ ). When compared to soybeans (Salunkhe et al. 1992), samples of E. cyclocarpum showed higher values in methionine, tyrosine, lysine, histidine, alanine, glycine,

Table 4. Amino acids from Enterolobium cyclocarpum mature seeds from different collection sites referenced to the Food and Agricultural Organization standard (WHO 2007) (g 100 $\mathrm{g}^{-1}$ ) and soybean.

Aminoácidos de semillas maduras de E. cyclocarpum de los diferentes sitios de colecta, referidos a los estándares de la Organización para la alimentación y la agricultura FAO/WHO/UNU (g $\left.100^{-1} \mathrm{~g}^{-1}\right)$ y a la soya.

\begin{tabular}{|c|c|c|c|c|c|c|c|c|}
\hline \multirow[b]{2}{*}{ Amino acid } & \multicolumn{7}{|c|}{ Collection site $(\bar{x} \pm s d)$} & \multirow[b]{2}{*}{$\begin{array}{c}\text { Soybean } \\
\text { (Salunkhe et al. 1992) }\end{array}$} \\
\hline & Tomatlán & $\begin{array}{l}\text { Puerto } \\
\text { Vallarta }\end{array}$ & Autlán & La Huerta & Amatitán & $\begin{array}{l}\text { Amino acids } \\
\text { (mean) }\end{array}$ & $\begin{array}{c}\text { FAO } \\
(2007)\end{array}$ & \\
\hline Tyrosine & $4.82 \pm 0.09$ & $5.38 \pm 0.41$ & $5.24 \pm 0.32$ & $6.06 \pm 0.19$ & $4.57 \pm 0.19$ & 5.21 & \multirow{2}{*}{4.6} & 3.8 \\
\hline Phenylalanine ${ }^{(*)}$ & $3.69 \pm 0.02$ & $4.27 \pm 0.38$ & $4.35 \pm 0.14$ & $4.54 \pm 0.22$ & $3.54 \pm 0.11$ & 4.08 & & 5.0 \\
\hline Isoleucine & $3.65 \pm 0.03$ & $4.11 \pm 0.64$ & $4.61 \pm 0.22$ & $4.75 \pm 0.11$ & $3.53 \pm 0.04$ & 4.13 & 3.1 & 4.6 \\
\hline Leucine & $7.16 \pm 0.09$ & $8.53 \pm 0.49$ & $8.05 \pm 0.25$ & $8.61 \pm 0.25$ & $6.83 \pm 0.43$ & 7.84 & 6.3 & 7.8 \\
\hline Lysine & $7.13 \pm 0.23$ & $8.06 \pm 0.77$ & $7.02 \pm 0.65$ & $7.66 \pm 2.43$ & $5.90 \pm 4.14$ & 7.15 & 5.2 & 6.4 \\
\hline Methionine $^{(*)}$ & $1.75 \pm 0.07$ & $1.77 \pm 0.46$ & $1.85 \pm 0.30$ & $2.20 \pm 0.15$ & $4.18 \pm 4.89$ & 2.35 & 2.6 & 1.1 \\
\hline Threonine & $3.67 \pm 0.19$ & $3.22 \pm 1.59$ & $3.15 \pm 1.31$ & $5.02 \pm 0.24$ & $3.93 \pm 0.49$ & 3.80 & 2.7 & 3.9 \\
\hline Valine & $3.93 \pm 0.04$ & $4.24 \pm 0.90$ & $4.72 \pm 0.38$ & $4.94 \pm 0.12$ & $3.82 \pm 0.11$ & 4.33 & 4.2 & 4.6 \\
\hline Aspartic acid & $8.70 \pm 0.15$ & $9.46 \pm 1.46$ & $10.05 \pm 0.9$ & $11.77 \pm 0.2$ & $8.86 \pm 0.56$ & 9.77 & -- & --- \\
\hline Alanine & $3.99 \pm 0.03$ & $4.79 \pm 0.19$ & $4.57 \pm 0.55$ & $5.47 \pm 0.23$ & $4.31 \pm 0.23$ & 4.63 & --- & 4.3 \\
\hline Arginine & $6.92 \pm 0.21$ & $7.43 \pm 0.47$ & $7.76 \pm 0.43$ & $8.61 \pm 0.11$ & $6.17 \pm 0.20$ & 7.38 & --- & 7.3 \\
\hline Glycine & $4.10 \pm 0.19$ & $4.10 \pm 1.04$ & $4.17 \pm 0.81$ & $5.63 \pm 0.6$ & $4.51 \pm 0.32$ & 4.50 & --- & 4.3 \\
\hline Histidine & $3.41 \pm 0.59$ & $3.93 \pm 1.56$ & $4.54 \pm 0.53$ & $4.26 \pm 0.16$ & $3.32 \pm 0.43$ & 3.89 & 1.8 & 2.6 \\
\hline Serine & $4.57 \pm 0.15$ & $5.50 \pm 0.34$ & $4.93 \pm 0.97$ & $6.81 \pm 0.94$ & $5.94 \pm 1.01$ & 5.55 & --- & 5.5 \\
\hline (mean) & 4.82 & 5.34 & 5.36 & 6.17 & 4.96 & --- & --- & --- \\
\hline
\end{tabular}

${ }^{(*)}$ Limiting amino acid. 
lesser values in isoleucine, phenylalanine, threonine and valine, and similar values in leucine, arginine and serine.

\section{DISCUSSION}

Protein content found in the seeds of E. ciclocarpum is similar to those reported for the other common legumes such as bean (Phaseolus vulgaris L.) at $20.12 \%$ (Ibrahim et al. 2012), chick-pea (Cicer arietinum L.) with $26.2 \%$, and green pea (Pisum sativum L.) with 21.3 \% (ConklinBrittain et al. 1999); compare favorably to cereals such as maize (Zea mays L.) with 7.6-10.2 \% (Zárate et al. 2004), and sorghum (Sorghum vulgare L.) with 6 to $19.6 \%$ (Brestenský et al. 2012); however they are lower than the $40 \%$ of protein content in soybean (Solano et al. 2012). Crude fiber, carbohydrates, ether extract and some minerals are also favorable. These parameters should be viewed from a holistic view. Carbohydrates (NFE) results are similar to those found in other legumes such as common bean with 60-65 \% (Sabuola et al. 2012). Carbohydrate fibers provide bulk character in food and are resistant to hydrolysis by enzymes, contributing also to absorption of water in the digestive tract (Sabuola et al. 2012). The ether extract values shown by E. cyclocarpum are similar to those shown by other legumes such as soybean meal (1.9\%) (Rodrigues et al. 2014) or faba bean (0.94 \%) (Güzel and Sayar 2012). Lipids are an important source of energy and essential fatty acids (linoleic and linolenic acids), highly digestible by animals. They contain 2.25 times the energy found in carbohydrates (Ball et al. 2001). Total digestible nutrients values are higher than those reported for beans (61.13 to 65.43 \%) (Abd El-Salam et al. 2013). Likewise, metabolisable energy values for E. ciclocarpum seeds are higher than those reported in conventional crops such as beans and peas (1318-1394 kJ 100-1 $\mathrm{g}^{-1}$ ) (Vadivel and Janardha-

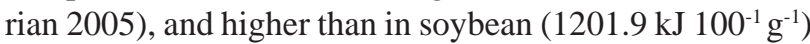
(Dourado et al. 2009).

Regarding collection sites, E. cyclocarpum seeds from Autlán and Tomatlán show the best nutritional properties. Thus, seeds from Autlán show the highest content in crude protein, ether extract, histidine, nitrogen and phosphorus; while seeds from Tomatlán exhibit the highest potassium and sodium content, and the second largest crude protein content. Furthermore, seeds from Autlán and Tomatlán also show the best digestibility (dry matter digestibility) properties. This could be explained by their high crude protein and ether extract values when contrasted with seeds from other collection sites. In contrast, although seeds from La Huerta and Amatitán show the highest total digestible nutrients and metabolisable energy values, seeds from Autlán and Tomatlán outdo them in the dry matter digestibility test. In addition, the soil of Autlán shows the highest content of soil organic matter, soil organic carbon and phosphorus, while in contrast Puerto Vallarta, La Huerta and Amatitán are the sites with the lowest soil characteristics in the above parameters. High content of soil organic mat- ter (humus) is an important factor on the fertility and productivity of ecosystems because it is involved in the biological, chemical, and physical processes of the soil, such as water infiltration, water holding capacity, aeration and promotion of root growth that these trees require in order to support their large volume of biomass (Croswell and Lefroy 2001). Nitrogen as soil supply generally increases foliage protein content and can increase forage palatability (Rivera and Parish 2010). Phosphorus, potassium, and some other nutrients in soils that increase biomass yield, may slightly reduce its quality, due to promotion of rapid growth (Ball et al. 2001).

\section{CONCLUSIONS}

A direct comparison among samples and their relation with environmental, geographical and edaphic conditions allows observing a clear difference in the nutrimental parameters of the seeds from different sites.

Seeds collected from the locations near Autlán and Tomatlán show the best nutrimental characteristics. Soil quality, soil organic matter, soil organic carbon, water availability, mineral content and ecological conditions at these sites could have been favorable factors to account for their good nutritional content.

Environment of tropical zones, warm and dry, together with the other factors listed above, would contribute significantly to the nutritional values found in E. cyclocarpum seeds, confirming it as an alternative source of feed and food, inasmuch as these seeds possess comparable content of crude protein to other well-known edible legumes such as the common bean, the chick-pea and the green pea. Although lower than the protein content of soybean, parota seeds have a similar amino acid profile, with somewhat better content in lysine and methionine, including other amino acids.

It is interesting to observe that although semi-evergreen jungle-like lush vegetation characterizes Puerto Vallarta site, the nutritional properties of the seeds are not the best, probably due to, among other factors, unfavorable soil properties.

\section{REFERENCES}

Abd El-Salam MS, LM El-Metwally, HM Abd El-Ghany, M Hozayn. 2013. Potentiality of using mungbean as a summer legume forage crop under Egyptian condition. Journal of Applied Sciences Research 9(2): 1238-1243.

Perkin Elmer. 1996. AY-1-Analysis of Soils: Extractable cations. In The Perkin-Elmer Corporation ed. Analytical Methods for Atomic Absorption Spectroscopy. Waltham, Massachusetts, USA. 300 p.

AOAC (Association of Official Analytical Chemists, US). 1990. Official methods of analysis. 15th edition. Washington DC, USA.

Adams RS, JH Moore, EM Kesler, GZ Stevens. 1964. New relationships for estimating TDN content of forage from chemical composition. Journal of Dairy Science 47: 1461. 
Andrade JH, H Esquivel, M Ibrahim. 2008. Disponibilidad de forrajes en sistemas silvopastoriles con especies arbóreas nativas en el trópico seco de Costa Rica. Zootecnia Tropical 26: 289-292.

Ball DM, M Collins, GD Lacefield, NP Martin, DA Mertens, KE Olson, DH Putnam, DJ Undersander, MW Wolf. 2001. Understanding forage quality. Park Ridge, IL, USA. American Farm Bureau Federation Publication 1-01. 21 p.

Bressani R, LG Elias. 1980. Nutritional value of legume crops for humans and animals. In Summerfield RJ, AH Bunting eds. Advances in legume science. London, England. Her Majesty's Stationary Office. p. 135-55.

Brestenský M, S Nitrayová, P Patráš, J Heger. 2012. The quality of sorghum grain in aspect of utilization amino acids. Journal of Microbiology, Biotechnology and Food Sciences 1 (February Special issue): 1032-1039.

Castro GH, TJ Nahed, A Tewolde, PR Ruiz, MJ López. 2006. Áreas con potencial para el establecimiento de árboles forrajeros en el centro de Chiapas. Técnica Pecuaria en México 2: 219-230.

Conklin-Brittain NL, ES Dierenfeld, RW Wrangham, M Norconk, SC Silver. 1999. Chemical protein analysis - a comparison of Kjeldahl crude protein and total ninhydrin protein from wild tropical vegetation. Journal of Chemical Ecology 25(12): 2601-2622.

Croswell ET, RDB Lefroy. 2001. The role and function of organic matter in tropical soils. Nutrient Cycling in Agroecosystems 61: 7-18.

Dodd NK, P Pushpamma. 1980. Effects of locate and varieties on protein, amino acids and mineral contents of Chick pea. Indian Journal of Agricultural Sciences 50: 139-144.

Dourado LRB, NK Sakomura, NAA Barbosa, MA Bonato, IM Kawuauchi, JBK Fernandes, FGP Costa. 2009. Corn and soybean meal Metabolizable energy with the addition of exogenous enzymes for poultry. Brazilian Journal of Poultry Science 11(1): 51-55.

FAO (Food and Agricultural Organization of the United Nations, IT). 2010. Evaluación de los recursos forestales mundiales 2010: Informe nacional México. Departamento Forestal-FAO. FRA2010/132, Roma, Italia. p. 98. Accessed on September 10, 2013. Available in http://www.fao.org/docrep/013/al567s/al567s.pdf

Güzel D, S Sayar. 2012. Effect of cooking methods on selected physicochemical and nutritional properties of barlotto bean, chickpea, faba bean, and white kidney vean. Journal of Food Science and Technology 49(1):89-95.

García E. 1973. Modificaciones al sistema de clasificación climática de Köppen (para adaptarlo a las condiciones de la República Mexicana). Segunda edición. México, D.F., México. Instituto de Geografía, UNAM. 246 p.

Ibrahim M, M Ayub, A Tanveer, M Yaseen. 2012. Forage quality of maize and legumes as monocultures and mixtures at different seed ratios. Journal of Animal and Plant Sciences 22(4): 987-992.

INE (Instituto Nacional de Ecología, MX). 1994. Estudio de ordenamiento ecológico de costa alegre, Jalisco Vol. 1. Jalisco, México. Instituto de Ecología. 274 p. Accessed on January 05, 2013. Available in http://repositorio.inecc.gob. mx/pdf/AE_010258/AE_010258_1.pdf

Lawal OS, KO Adebowale. 2006. The acylated protein derivates of Cavalia ensiformis (Jack bean): A study of functional characteristics. LWT - Food Science and Technology 39: 918-929.

Liu K. 1997. Soybeans, chemistry, technology and utilization. New York, USA. Chapman and Hall. 532 p.

Pennington TD, J Sarukhán. 1968. Árboles tropicales de México. México D.F., México. INIF/FAO. 413 p.

Pennington TD, J Sarukhán. 2005. Árboles tropicales de México: manual para la identificación de las principales especies. $3^{\mathrm{a}}$ edición. México D.F., México. Fondo de Cultura Económica. 523 p.

Rivera D, J Parish. 2010. Interpreting forage and feed analysis reports. Starkville, MS, USA. Mississippi State University, Extension Service. 8 p.

Rocha OJ, JA Lobo-Segura. 1996. Genetic variation and differentiation among five populations of the guanacaste tree (Enterolobium cyclocarpum). International Journal of Plant Sciences 157 (2): 234-239.

Rodrigues MAM, AL Lourenço, JW Cone, FM Nunes, AS Santos, JMM Cordeiro, CMV Guedes, LMM Ferreira. 2014. Evaluation of the nutritive value of muiumba (Baikiaea plurijuga) seeds: chemical composition, in vitro organic matter digestibility and in vitro gas production. SpringerPlus 3:311. doi:10.1186/2193-1801-3-311

Ruiz-C JA, HE Flores-L, JR Regalado-R, G Ramírez-O. 2012. Estadísticas climáticas del estado de Jalisco, libro técnico No. 12. Campo Experimental Centro Altos de Jalisco. Jalisco, México. Instituto Nacional de Investigaciones Forestales, Agrícolas y Pecuarias. Centro de Investigación Regional del Pacífico Centro. 350 p.

Ruiz MA, A Sotelo. 2001. Chemical composition, nutritive value, and toxicology evaluation of Mexican wild lupins. Journal of Agricultural and Food Chemistry 49:5336-5339.

Rzedowski J. 1991. Diversidad y orígenes de la flora fanerogámica de México. Acta Botánica Mexicana 14: 3-21.

Sabuola F, Y Widodo, T Kehinde. 2012. Processing and utilization of legumes in the tropics. In Teched. Vital Food and Control Engineering. p. 3-84. Accessed on february 18, 2014. Available in http://cdn.intechopen.com/pdfswm/35126.pdf

Salunkhe DK, JK Chavan, RN Adsule, SS Kadam. 1992. World oilseeds: chemistry, technology, and utilization. Reinhold, New York, USA. Van Nostrand. 554 p.

Schoenmaker NJ, AC Beynen. 2001. De samenstellingvan commercie" le beovoeders met bijzondere aandacht voor het ijzergehalte. Tijdschrift voor Diergeneeskunde 126: 620-623.

Sedeur (Secretaria de Desarrollo Urbano y Ecología). 2010. Plan de desarrollo de la región 11, Valles, Jalisco. 2da. edición. Jalisco, México. Gobierno de Jalisco. 211 p. Accessed on february 18, 2014. Available in http://transparencia.info. jalisco.gob.mx/sites/default/files/plan_de_desarrollo_region_11_valles_vp1_0. pdf

Serratos-A JC, J Carreón-A, H Castañeda-V, P Garzón-De la Mora, J García-E. 2008. Composición químico-nutricional y de factores antinutricionales en semillas de parota (Enterolobium cyclocarpum). Interciencia 33 (11): 850-854.

Solano G, R Fonseca, R Santiesteban. 2012. Proteína, aminoácidos y grasa en el grano de variedades de soya (Glycine max (L.) Merry) cultivadas en el oriente de cuba. Revista Computadorizada de Producción Porcina 19(4): 241-245.

Sotelo A. 1981. Leguminosas silvestres, reserva de proteínas para la alimentación del futuro. ICT 3: 28-32. 
Sousa M, A Delgado. 1993. Mexican Leguminosae: phytogeography, endemism, and origins. In Ramamoorthy T, R Bye, J Fa eds. Biological diversity of México: origins and distribution. New York, USA. Oxford University Press. p. 459-513.

Urribarrí-C L, A Ferrer-O, A Colina. 2004. Extracción y precipitación de las proteínas solubles del pasto elefante enano (Pennisetum purpureum Schum cv. Mott). Revista de la Facultad de Agronomía - LUZ 21: 264-275.

USDA (United States Department of Agriculture, US). 1999. Soil taxonomy. A basic system of soil classification for making and interpreting soil surveys. In Agriculture Handbook, United States Department of Agriculture, USA. Second edition. 869 p. Accessed on November 10, 2013. Available in http://www.itc.nl/ rossiter/Docs/NRCS/tax.pdf

Vadivel V, K Janardharian. 2005. Nutritional and antinutritional characteristics of seven south Indian wild legumes. Plant Foods for Human Nutrition 60: 69-75.

Vázquez-Yanes C, I A Batis Muñoz, MI Alcocer Silva, M Gual
Díaz, C Sánchez Dirzo. 1999. Árboles y arbustos potencialmente valiosos para la restauración ecológica y la reforestación. Reporte técnico del proyecto J084. CONABIO - Instituto de Ecología, UNAM. Accessed on february 26, 2014. Available in http://www.conabio.gob.mx/conocimiento/ info_especies/arboles/doctos/inicio.pdf

WHO (World Health Organization, CH). 2007. Protein quality evaluation. Chapter 6. In WHO/FAO/UNU eds. Protein and amino acid requirements in human nutrition report of a joint. WHO Technical Report Series 935. Geneva, Switzerland. p 93-102.

Yi H, GE Ravilious, A Galant, HB Krishnan, JM Jez. 2010. From sulfur to homoglutathione: thiol metabolism in soybean. Amino Acids 39: 963-978.

Zarate AJ, ET Moran, HL Stilborn. 2004. Comparison of normal dent with waxy, high-oil and waxy-high-oil corns on pellet quality of associated feeds and response by broilers. Journal of Applied Poultry Research 13: 650-659. 
